\title{
BIOLOGY OF THE SPIDER Peucetia arabica SIMON, 1882 (ARANEAE: OXYOPIDAE) UNDER LABORATORY CONDITIONS.
}

Gihan M.E. Sallam and Nahla A.I. Abd El-Azim

Plant Protection Research Institute, Agric. Research Centre, Dokki, Giza, Egypt

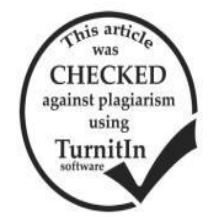

\section{ABSTRACT}

The spider Peucetia arabica Simon, 1882 was found among wild plants in Gebel Elba, Red Sea Governorate, Egypt. Its life cycle was studied in laboratory. Males reached maturity after 7 spiderlings instars lasted (308 \pm 2.34 days), while females passed through 8 spiderlings instars durated $(345 \pm 11.5$ days). Different instars were reared on different stages of larvae of cotton leaf worm Spodoptera littoralis (Boisd.). Food consumption was also noticed, in addition to, mating behavior was observed.

Keywords : Spiders, Life cycle, Feeding, Mating behavior, Oxyopidae, Peucetia arabica, Egypt.

\section{INTRODUCTION}

All spiders are exclusively carnivores and feed almost upon prey which they have caught for themselves. They prey upon other arthropods, mainly insects, although woodlice and centipedes may also be taken. It is important to study the different biological aspects of the spiders to maximize their important role as biological control agents, Ghabbour et al. (1999) and Hussein et al. (1998). Family Oxyopidae Thorell, 1870, has a moderate number among 114 families recorded all over the world. From this family, 453 species of were recorded, belong to 9 genera are distributed all over the world (World Spider Catalog, 2015) while, in Egypt, two genera and six species are recorded (El-Hennawy, 2006).

Lynx spider is the common name for any member of the family Oxyopidae. Most species make little use of webs, instead spending their lives as hunting spiders on plants.

There are several genera of family Oxyopidae and they differ in their habits and adaptations. Most of them have large spiny bristles on their legs and in many species the bristles form almost a basket-like structure that may assist in confining the prey that they grasp, and protect the spider from its struggles. Peucetia species on the other hand, commonly are larger. They are rangy and their camouflage is vivid green, adapted to hunting or hiding among foliage. Lynx spiders, in spite of being largely ambush hunters, are very speedy runners and leapers, alert and with good vision (Aviles, 1994).

Peucetia Thorell, 1869 has three species in Egypt, Peucetia arabica Simon, 1882, Peucetia virescens (O.P.-Cambridge, 1872) and Peucetia viridis (Blackwall, 1858) (El-Hennawy, 2006).

Peucetia arabica, Simon, 1882 was recorded from Cairo, Abu Galoum, Nabq, Ras Mohammed, St. Catherine, Siwa Oasis, Suez (El-Hennawy, 2006). There are no studies on Peucetia arabica in Egypt until now, therefore, the present study aims to through some light on biological aspects as well as its role in the agro ecosystem.

\section{MATERIALS AND METHODS}

\section{A-Rearing of spiders:-}

Adult female and male of Peucetia arabica, Simon, 1882 were collected on February 2014 in Gebel Elba, Red Sea Governorate, Egypt. They were found among wild plants, Tarfa (Tamarix sp.). After transferred them to the laboratory, the female preyed on the male and this behavior was considered as the mating date. After that the female was reared inside a test tube where she laid two egg sacs on 14 March and 28 April, 2014 which were observed till hatching. The hatched spiderlings were reared individually inside translucent plastic containers (3 $\mathrm{cm}$ in diameter and $5 \mathrm{~cm}$ in length); the upper lid of the container was perforated for ventilation. All obtained spiderlings were reared under laboratory conditions $\left(26-28^{\circ} \mathrm{C}\right.$ and $60-70 \%$ R.H.). They were fed once every two days on different stages $\left(1^{\text {st }}\right.$ $4^{\text {th }}$ instars) of larvae of the cotton leaf worm, Spodoptera littoralis (Boisduval, 1833). 41 individuals reached to adult.

After reaching adulthood, three pairs of males and females were reared in separate containers to observe mating behavior and oviposition recording the biological aspects. Under laboratory conditions (26-28 ${ }^{\circ} \mathrm{C}$ and $60-70 \%$ R.H.).

\section{B- Rearing of insect prey :-}

Cotton leaf worm Spodoptera littoralis was reared using a method described by Mostafa (1988). Field- collected egg batches of $S$. littoralis were cultured on castor bean leaves (Ricinus communis L.) in glass jars (20 cm diameter by $15 \mathrm{~cm}$ height). The leaves were washed and cleaned. The jars were covered with muslin cloth held in position by rubber bands and kept in an incubator at $25^{\circ} \mathrm{C}$ and $60-70 \%$ R.H. The jars were daily examined. Adult moths were confined in glass chimneys as oviposition cages and were provided with Nerium leaves (Nerium oleander) as oviposition sites. These oviposition cages were provided with pieces of cotton soaked in $10 \%$ sugar solution for adult nourishment. The obtained eggs were re-cultured as mentioned above. The batches were left until hatching and the different larval instars were taken as introduced prey to the spider.

\section{RESULTS AND DISCUSSION}

\section{Egg sac, eggs and incubation period}

After mating, the female lasted 20 days to form the eggs, the period is considered as the pre-oviposition period.

The laid egg sac was pyramid-shaped, covered with flock (fig.1), green in color at first and became darker before hatching; the female is always laying on 
eggs guard it (fig.2). The eggs inside the egg sac were circular and yellow at the beginning after laying and became dark before hatching.

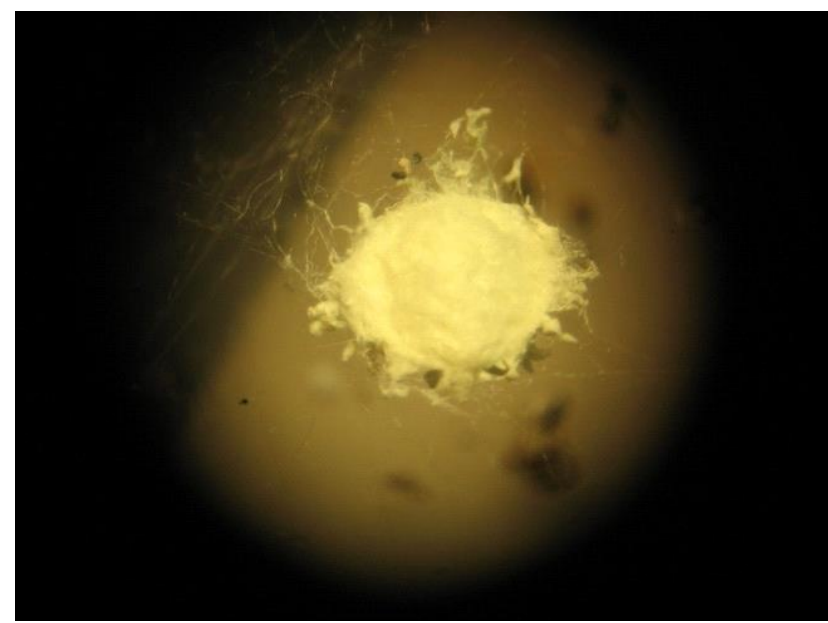

Figure (1): Egg Sac Shape

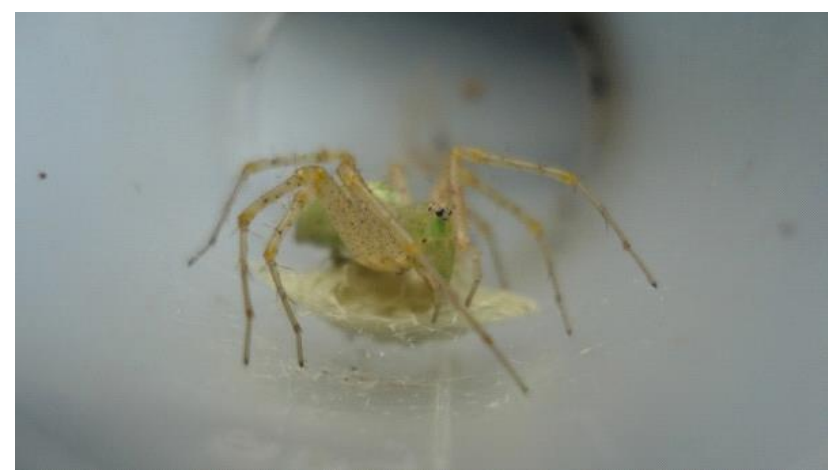

Figure (2): Adult female guarding the egg sac

The incubation period of eggs of $P$. arabica lasted 31 and 35 days for the first egg sac while the second one, the incubation period lasted after 20 and 25 days respectively.
The two egg sacs which have been laid throw this experiment; the individuals emerged on two stages. 68 individuals hatched from the first egg sac on two stages (31 and 37 individuals) on 14 and 20 March 2014 respectively. 43 individuals hatched from the second egg sac on two stages also, (23 and 20 individuals) on 18 and 23 May, 2014 respectively.

From the previous egg sacs, 111 individuals hatched and emerged through a round pore at the tip of the egg sac (fig.3), they were reared under laboratory conditions. Only 41 of them reached maturity and completed the life cycle.

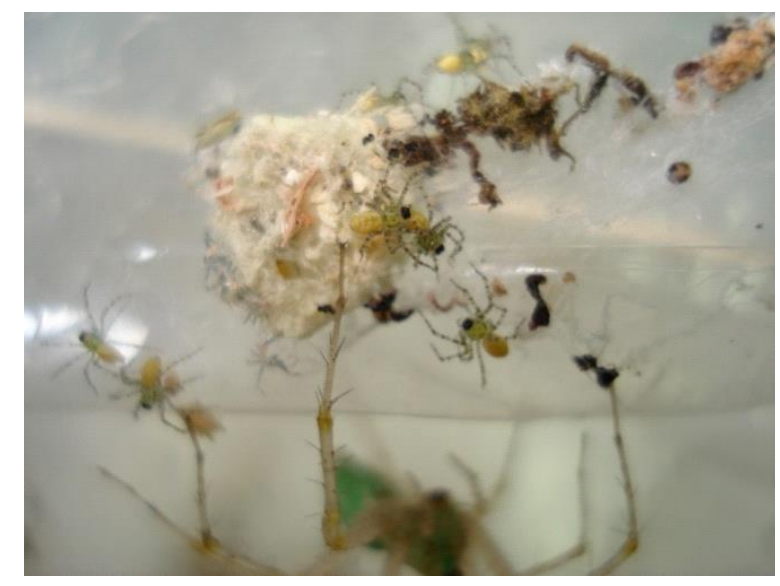

Figure (3): Spiderlings

Spiderlings

The spiderlings passed through 7 instars for males and 8 instars for females during their development (Table 1), this agrees with Steatoda paykulliana (Theridiidae) which passed through 7-8 instars for male and female, respectively (Sallam, 2004). The longest duration was that of the $8^{\text {th }}$ instar of female and the $5^{\text {th }}$ instar of male. The shortest instar was the $1^{\text {st }}$ instar for both male and female, respectively.

Table 1: Duration of the different developmental stages of the Oxyopidae spider $P$. arabica when fed on $S$. littoralis .

\begin{tabular}{|l|c|c|c|c|}
\hline \multirow{2}{*}{ Developmental Stage } & \multicolumn{4}{|c|}{ Duration (Days) } \\
\cline { 2 - 5 } & \multicolumn{3}{|c|}{ Male } & \multicolumn{2}{c|}{ Female } \\
\cline { 2 - 5 } & Range & Mean \pm SE & Range & Mean \pm SE \\
\hline $1^{\text {st }}$ Instar & $17-26$ & $22 \pm 0.63$ & $14-35$ & $22 \pm 0.8$ \\
\hline $2^{\text {nd }}$ Instar & $21-46$ & $35 \pm 1.25$ & $30-59$ & $38 \pm 1.4$ \\
\hline $3^{\text {rd }}$ Instar & $42-67$ & $49 \pm 1.4$ & $30-62$ & $40 \pm 1.25$ \\
\hline $4^{\text {th }}$ Instar & $25-52$ & $39 \pm 1.25$ & $23-57$ & $38 \pm 1.4$ \\
\hline $5^{\text {th }}$ Instar & $50-86$ & $60 \pm 1.4$ & $24-71$ & $38 \pm 1.5$ \\
\hline $6^{\text {th }}$ Instar & $21-45$ & $35 \pm 1.1$ & $19-45$ & $36 \pm 1.04$ \\
\hline $7^{\text {th }}$ Instar & $25-57$ & $41 \pm 1.4$ & $25-57$ & $45 \pm 1.5$ \\
\hline $8^{\text {th }}$ Instar & - & - & $60-88$ & $75 \pm 1.1$ \\
\hline Incubi. & $20-31$ & $27 \pm 0.9$ & $20-31$ & $25 \pm 0.9$ \\
\hline Life cycle & $287-337$ & $308 \pm 2.34$ & $326-428$ & $345 \pm 11.5$ \\
\hline
\end{tabular}

\section{Sex ratio}

The sex ratio of adults was 1: 1.56 (male: female) (fig.4), this differed from that of another species belong to family Theridiidae, Steatoda paykulliana which was
1: 1.35 (Sallam, 2004) but they have a similar long life cycle. 

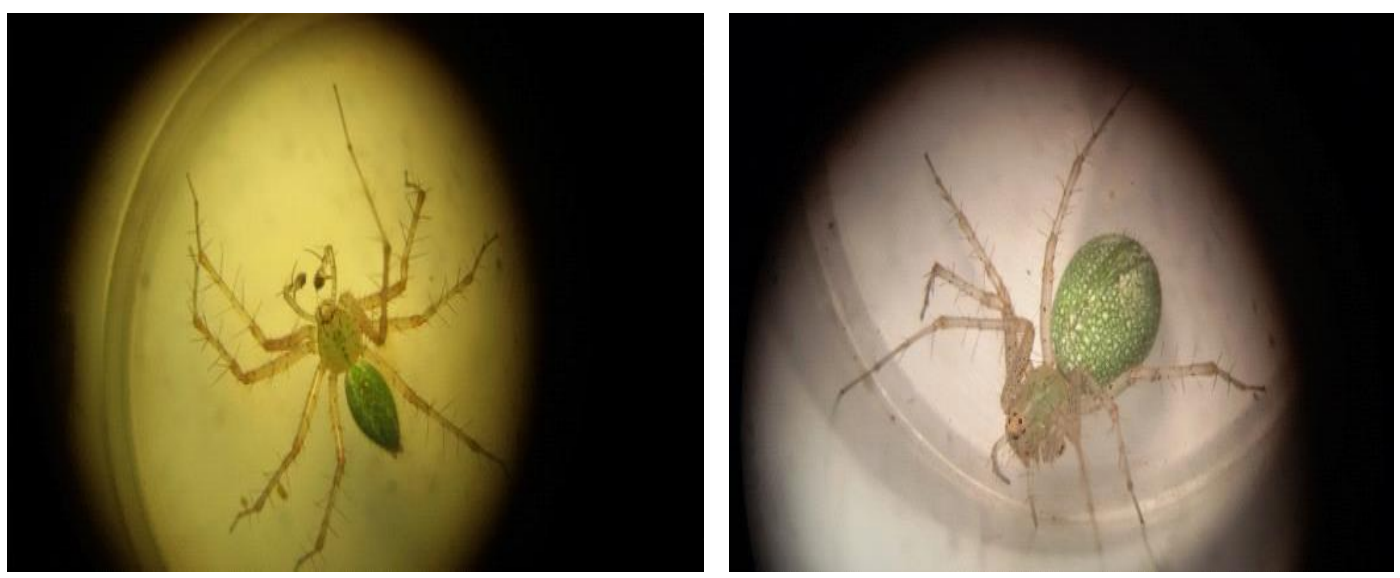

Figure (4): Adult Male and Female

\section{Food consumption}

During the study of food consumption of Peucetia arabica, different spiderling instars and adults were fed on various instars of $S$. littoralis larvae. Both first and second instars of spiderlings were fed on the first instar of $S$. littoralis. Third and fourth instars of spiderlings were fed on the second instar of prey. Fifth and sixth instars of spiderlings were fed on the third instar of the prey, while the seventh and eighth instars of spiderlings were fed on the fourth instar of the prey.

Number of consumed prey by different spiderling instars is in Table 2. The biggest numbers of consumed prey was that of the $6^{\text {th }}$ instar (105 prey) of female and the $5^{\text {th }}$ instar (103 prey) of male while, the lowest numbers of consumed prey was that of the $2^{\text {nd }}$ instar (10 prey) and $1^{\text {st }}$ instar (15 prey) for both male and female, respectively.

Table 2: Food consumption of the spider Oxyopid, $P$. arabica when fed on $S$. littoralis .

\begin{tabular}{|c|c|c|c|c|}
\hline \multirow{3}{*}{ Developmental Stage } & \multicolumn{4}{|c|}{ Number of consumed individuals of prey } \\
\hline & \multicolumn{2}{|c|}{ Male } & \multicolumn{2}{|c|}{ Female } \\
\hline & Range & Mean \pm SE & Range & Mean \pm SE \\
\hline $1^{\text {ST }}$ Instar & $15-30$ & $21.6 \pm 06$ & $15-29$ & $22 \pm 0.5$ \\
\hline $2^{\text {nd }}$ Instar & $10-30$ & $17.1 \pm 0.8$ & $18-33$ & $21 \pm 0.7$ \\
\hline $3^{\text {rd }}$ Instar & $15-35$ & $23.4 \pm 0.9$ & $20-61$ & $28 \pm 1.4$ \\
\hline $4^{\text {th }}$ Instar & $44-81$ & $49.1 \pm 1.5$ & $34-66$ & $44 \pm 1.5$ \\
\hline $5^{\text {th }}$ Instar & $88-120$ & $99.3 \pm 1.4$ & $120-160$ & $129 \pm 1.5$ \\
\hline $6^{\text {th }}$ Instar & $99-135$ & $105 \pm 1.5$ & $92-128$ & $100 \pm 1.5$ \\
\hline $7^{\text {th }}$ Instar & $80-110$ & $91.4 \pm 1.5$ & $83-125$ & $91 \pm 1.5$ \\
\hline $8^{\text {th }}$ Instar & - & - & $58-100$ & $69 \pm 1.5$ \\
\hline Life cycle & $379-462$ & $407 \pm 3.5$ & $483-564$ & $483 \pm 15.7$ \\
\hline
\end{tabular}

\section{Mating behavior}

The mating behavior of two couple of male and female of Peucetia arabica was observed. Mating process was achieved through the following steps:

1. The approach of both the male and the female towards each other until touching of their legs.

2. Rubbing male's pedipalps by each other.

3. More approach between male and female and overlapping of their legs.

4. Pedipalp of male comes in contact with cephalothorax of female trying to reach the epigynum (about 5 times).

5. Male inserts the left palpal organ inside the epigynum of female with contracting and relaxing the male abdomen (10 minutes).

6. Male leaves the female with rubbing the pedipalps with each other.

7. Female comes near the male which repeats the steps $3-5$ but with the right palpal organ ( 8 minutes).
Notes on mating and devouring

1. On the first couple, the female mated with male and devour him then put the egg sac.

2. On the second couple, female did not mate with male and not devour him but they stay together for long time without mating or devouring.

It is obvious that devouring male in this species is not related to mating with female. They may live in the same area for a few days without cannibalism.

\section{Acknowledgment}

The authoresses are indebted to Col. Hisham K. El-Hennawy (Arachnid collection of Egypt) who identified the species and kindly revised a draft of the manuscript.

\section{REFERENCES}

Aviles, Leticia (1994): Social behaviour in a webbuilding lynx spider, Tapinillus spp. (Araneae, Oxyopidae) Biological J. the Linnean Society, 52 (2):163-176. 
El-Hennawy, H. K. (2006): A list of Egyptian spiders (revised in 2006). Serket, 10(2): 65-76.

Ghabbour S. I., A. M. Hussein and H.K. El-Hennawy (1999): Spider population associated with different crops in Menoufya Governorate. Nile Delta, Egypt. J. Agric. Res., 77 (3): 1163 1179.

Hussein, A. M.; H. K. El-Hennawy and A. A. Sayed (1998): Biodiversity of spiders (Araneae) in the western desert of Egypt in relation to agriculture and land reclamation. Bull. Fac. Agric. Cairo Univ., 49: $597-610$.
Mostafa, S. A. 1988. Effect of some insect growth regulators on some cotton pests. M.Sc. Thesis, Fac. Agric., Al- Azhar Univ. Egypt. 100pp.

Sallam, Gihan. M.E. (2004): Life cycle of Steatoda paykulliana (Walckenaer, 1805) in Egypt (Araneida: Theridiidae). Serket. 9(2): 37- 40.

World Spider Catalog (2015): World Spider Catalog. Natural History Museum Bern, online at http://wsc.nmbe.ch, version 16 , accessed on $\{1$ September 2015\}.

\section{بيولوجية المفترس العنكبوتى (Araneae: Oxyopidae) الظروف المعمليه

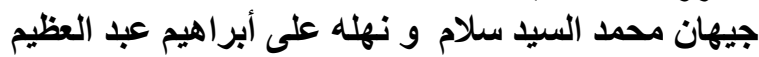

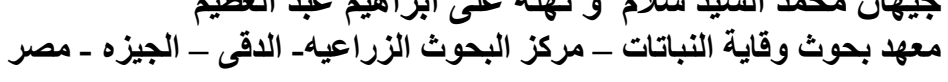

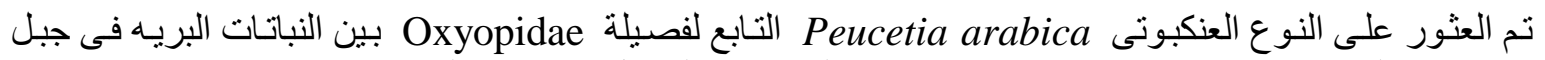

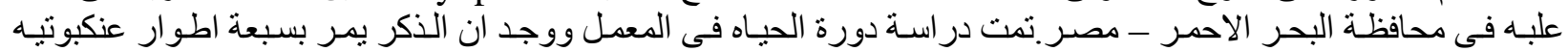

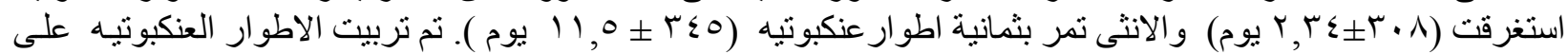

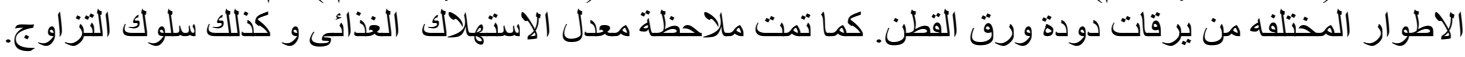

